\title{
Prof. Jan Walewski dyrektorem \\ Centrum Onkologii — Instytutu im. Marii Skłodowskiej-Curie
}

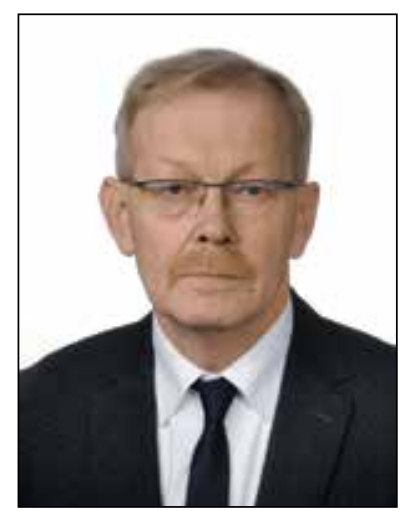

W dniu 16 marca $2016 \mathrm{r}$. prof. dr hab. n. med. Jan Walewski został powołany na dyrektora Centrum Onkologii — Instytutu im. Marii Skłodowskiej-Curie.

Prof. Jan Walewski jest specjalistą w dziedzinie chorób wewnętrznych, onkologii klinicznej, hematologii i transplantologii klinicznej. Jest absolwentem Wydziału Lekarskiego Akademii Medycznej w Warszawie, gdzie od trzeciego roku studiował w ramach indywidualnego programu pod kierunkiem prof. Tadeusza Koszarowskiego.

Od początku pracy zawodowej w 1977 r. zatrudniony jest w Centrum Onkologii — Instytucie im. Marii Skłodowskiej-Curie w Warszawie. Doktoryzował się w 1987 r. pod kierunkiem prof. Jana Steffena, stopień doktora habilitowanego uzyskał w 2002 r., a tytuł profesora nauk medycznych — w 2007. Od 2010 r. jest kierownikiem Kliniki Nowotworów Układu Chłonnego CO-I.

W ramach programu wymiany naukowej z amerykańskim National Cancer Institute pracował w latach 1987-88 i 1992 w Montefiore Medical Center/Albert Einstein College of Medicine, New York w zespole Petera H. Wiernika; uzyskał wówczas, po zdaniu egzaminu nostryfikacyjnego FMGEMS, uprawnienia lekarza. Odbył też liczne inne zagraniczne staże zawodowe i naukowe, m.in. w Cleveland Clinic Cancer Center,
Cleveland, USA (1995), St. Bartholomew's Hospital, Londyn (1993) oraz Fred Hutchinson Cancer Research Center/University of Washington, Seattle, USA (1999).

W 1996 r. wdrożył w Klinice Nowotworów Układu Chłonnego CO-I metodę intensywnej chemioterapii z wysokimi dawkami metotreksatu w leczeniu chorych na chłoniaka Burkitta. W 1997 r. wdrożył w CO-I, we współpracy z zespołem prof. Zygmunta Pojdy, program leczenia mieloablacyjnego i przeszczepiania komórek krwiotwórczych, realizowany i rozwijany aktualnie. W 2004 r. zainicjował włączenie warszawskiego CO-I do sieci międzynarodowej współpracy w ramach European Mantle Cell Lymphoma Network oraz European Leukemia Net, w ramach których realizuje jako koordynator i członek Writig/Steering Committee szereg prospektywnych badań klinicznych, w tym już opublikowanych w New England Journal of Medicine i Blood. Należał do grona współzałożycieli Polskiej Grupy Badawczej Chłoniaków (PLRG), której jest aktualnie wiceprezesem. Jest członkiem Rad Redakcyjnych pism: Nowotwory Journal of Oncology i Onkologia w Praktyce Klinicznej oraz ESMO Hematology Faculty Member.

Jego bibliografia liczy ponad 200 indeksowanych publikacji, IF prac pełnych oryginalnych 474 , liczba cytowań blisko 4000, indeks h:23. Jest członkiem PLRG, PALG, PTO, PTOK, PTHiT, ASH, ASCO, ESMO, EBMT oraz EORTC Lymphoma Group. Odznaczony jest Złotym Krzyżem Zasługi i Krzyżem Kawalerskim Orderu Odrodzenia Polski.Członek-założyciel NSZZSolidarność w 1980 r., delegat Regionu Mazowsze. Delegat na Okręgowy Zjazd Lekarzy w Warszawie w kadencjach1989-2009. 